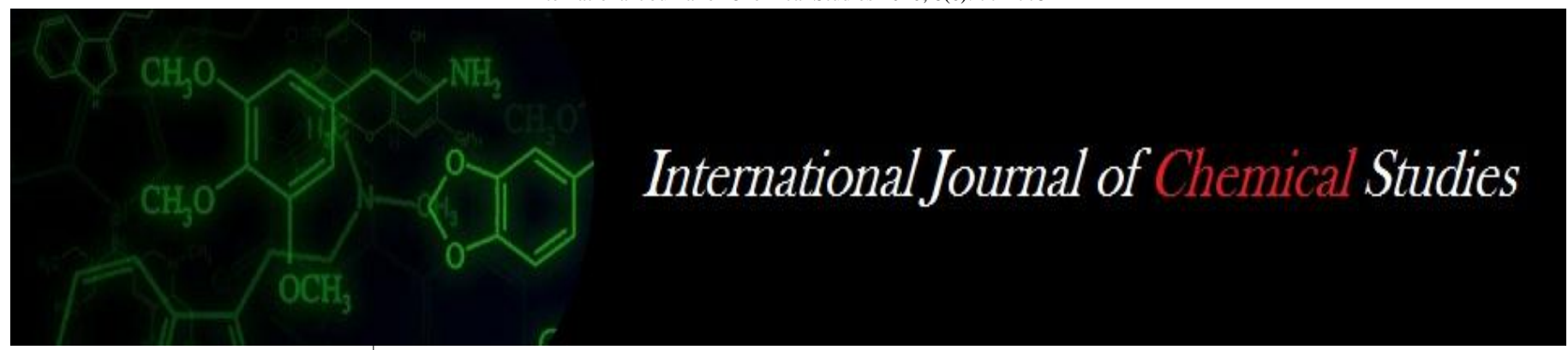

P-ISSN: 2349-8528

E-ISSN: 2321-4902

www.chemijournal.com

IJCS 2020; 8(6): 771-775

(C) 2020 IJCS

Received: 16-09-2020

Accepted: 25-06-2020

PB Motghare

P.G. Students, Agronomy

Section, College of Agriculture,

Nagpur, Maharashtra, India

\section{AL Uparkar}

P.G. Students, Agronomy

Section, College of Agriculture,

Nagpur, Maharashtra, India

\section{RS Marbate}

P.G. Students, Agronomy

Section, College of Agriculture,

Nagpur, Maharashtra, India

\section{CN Tekade}

P.G. Student, Agronomy

Section, P.G.I., M.P.K.V.,

Rahuri, Ahemadnagar,

Maharashtra, India

\section{VG Nagdeote}

Associate Professor of

Agronomy, Agronomy Section,

College of Agriculture Dr.

P.D.K.V., Akola, Nagpur,

Nagpur, Maharashtra, India

Corresponding Author:

PB Motghare

P.G. Students, Agronomy

Section, College of Agriculture,

Nagpur, Maharashtra, India

\section{Effect of cultural and chemical weed management on weed population and economics in drilled paddy (Oryza sativa $\mathbf{L}$.)}

\author{
PB Motghare, AL Uparkar, RS Marbate, CN Tekade and VG Nagdeote
}

DOI: https://doi.org/10.22271/chemi.2020.v8.i6k.10863

\begin{abstract}
An investigation was conducted at College of Agriculture, Nagpur to study the effect of Weed management in drilled paddy (Oryza sativa L.) during kharif season of 2014-2015. The experiment was laid down in Randomized block design having treatments viz., Control $\left(\mathrm{T}_{1}\right), 2$ hand weeding at 20 and 40 DAS $\left(\mathrm{T}_{2}\right)$, Butachlor @ $1500 \mathrm{~g}$ a.i. ha ${ }^{-1}$ at 7 DAS $\left(\mathrm{T}_{3}\right)$, Pretilachlor @ 750g a.i. ha ${ }^{-1}$ at $7 \mathrm{DAS}\left(\mathrm{T}_{4}\right), 2,4 \mathrm{D}$ @ $1000 \mathrm{~g}$ a.i. $\mathrm{ha}^{-1}$ at 20 - $25 \mathrm{DAS}\left(\mathrm{T}_{5}\right)$, Pyrazosulfuron ethyl @ $25 \mathrm{~g}$ a.i. ha ${ }^{-1}$ at $20-25 \mathrm{DAS}\left(\mathrm{T}_{6}\right)$,

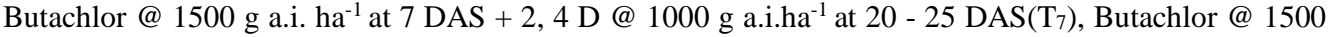
g a.i. ha ${ }^{-1}$ at 7 DAS + Pyrazosulfuron ethyl @ 25 g a.i.ha ${ }^{-1}$ at $20-25$ DAS(T8), Pretilachlor @ $750 \mathrm{~g}$ a.i. ha $^{-1}$ at 7 DAS + 2, 4 D @ 1000 g a.i. ha ${ }^{-1}$ at $20-25$ DAS(T9), Pretilachlor @ 750 g a.i. ha ${ }^{-1}$ at 7 DAS + Pyrazosulfuron ethyl @ $25 \mathrm{~g}$ a.i.ha ${ }^{-1}$ at $20-25 \mathrm{DAS}\left(\mathrm{T}_{10}\right)$ thereby making Ten treatment combinations replicated three times. Rice variety PKV- Khamang was used as a test crop. Results revealed that two hand weeding at 20 and 40 DAS $\left(\mathrm{T}_{2}\right)$ caused significant reduction in population of monocot and dicot weeds as compared to control and it was at par with butachlor@1500 g a.i. ha ${ }^{-1}$ at 7 DAS + 2,4-D @ $1000 \mathrm{~g}$ a.i. $\mathrm{g} \mathrm{ha}^{-1}$ at $20-25 \mathrm{DAS}\left(\mathrm{T}_{7}\right)$, butachlor @ $1500 \mathrm{~g}$ a.i. ha ${ }^{-1}$ at $7 \mathrm{DAS}+$ pyrazosulfuron ethyl @ 25 g a.i. ha ${ }^{-1}$ at 20 - 25 DAS (T8), pretilachlor@ 750 g a.i. ha ${ }^{-1}$ at 7 DAS + 2,4-D @ 1000 g a.i. ha ${ }^{-1}$ at 20 25 DAS ( $\left.\mathrm{T}_{9}\right)$ and pretilachlor @ $750 \mathrm{~g}$ a.i. ha ${ }^{-1}+$ pyrazosulfuron ethyl @ $25 \mathrm{~g}$ a.i. ha ${ }^{-1}$ at 20 - $25 \mathrm{DAS}$ $\left(\mathrm{T}_{10}\right)$. Lowest dry matter of weeds and higher weed control efficiency was recorded by treatment two hand weeding at 20 and 40 DAS $\left(\mathrm{T}_{2}\right)$ and it was at par with $\mathrm{T}_{7}, \mathrm{~T}_{8}, \mathrm{~T}_{9}$ and $\mathrm{T}_{10}$.

Maximum net return and B:C ratio were obtained by treatments two hand weeding at 20 and 40 DAS and was at par with butachlor @ $1500 \mathrm{~g}$ a.i. ha ${ }^{-1}$ at 7 DAS + 2,4-D @ $1000 \mathrm{~g}$ a.i. $\mathrm{g} \mathrm{ha}^{-1}$ at $20-25 \mathrm{DAS}\left(\mathrm{T}_{7}\right)$, butachlor@1500 g a.i. ha ${ }^{-1}$ at 7 DAS + pyrazosulfuron ethyl @ $25 \mathrm{~g} \mathrm{a.i.} \mathrm{ha}^{-1}$ at $20-25 \mathrm{DAS}\left(\mathrm{T}_{8}\right)$, pretilachlor@750 g a.i. ha ${ }^{-1}$ at 7 DAS + 2,4-D @ $1000 \mathrm{~g}$ a.i. ha ${ }^{-1}$ at $20-25$ DAS $\left(\mathrm{T}_{9}\right)$ and pretilachlor @ $750 \mathrm{~g}$ a.i. ha ${ }^{-1}+$ pyrazosulfuron ethyl @ 25 g a.i. ha ${ }^{-1}$ at $20-25$ DAS (T10).
\end{abstract}

Keywords: Monocot and dicot weed count, Butachlor, 2, 4-D, Pretilachlor, Pyrazosulfuron

\section{Introduction}

Rice (Oryza sativa L.) belongs to the family poaceae. Rice is one of the most important staple food grain crop of the world, which constitute the principle food for about 60 percent of the world's human population and two third of Indian population. Rice provides about 22 percent of the world's supply of calories and 17 percent of the proteins. It contains nearly about 70 percent carbohydrates and 6-7 percent protein. Biological value of its protein is high. It contains less fat i.e. 2-2.5 percent and much of the fat is lost during milling. It contains a low percentage of calcium. Also rice grain contains much ' $\mathrm{B}$ ' group vitamins and minerals. The production of Rice during the year 2013-14 was 106.54 Million Tonnes tones from 439.49 lakh ha area with productivity of $2424 \mathrm{~kg} \mathrm{ha}^{-1}$ (Anonymous, 2014) ${ }^{[1]}$.

Weed infestation is one of the limiting factors in rice production. Uncertain rainfall, lack of protective irrigation, attack of pest and disease reduces the rice yield. In cultivated rice field equilibrium in plant communities is not a static relationship. The species diversity varies with type of rice culture. Subramanian et al. (2006) reported that weed management in rice gave $50.7 \%$ additional grain yield over unweeded check. Reduction of yield due to weeds estimated to around $15-20 \%$ in transplanted rice, $30-35 \%$ for direct seeded rice and above $50 \%$ for upland rice. Mechanical and cultural methods are not always possible to be adopted on account of scarcity of labour in the peak period of rice transplanting. In such situation the herbicides are the only way to control weeds. At present, there are quite number of selective herbicides 
like butachlor, pendimethallin, benthiocarb, ronstar, pretilachlor, 2, 4-D, pyrazosulfuron ethyl and anilophos are used in paddy crop for weed control.

\section{Materials and Methods}

A field experiment was conducted at Agronomy farm, College of Agriculture, Nagpur during summer season of 2013-2014. The experiment was laid down in Randomized block design having treatments viz., Control $\left(\mathrm{T}_{1}\right), 2$ hand weeding at 20 and 40 DAS $\left(\mathrm{T}_{2}\right)$, Butachlor @ $1500 \mathrm{~g}$ a.i. ha ${ }^{-1}$ at 7 DAS $\left(\mathrm{T}_{3}\right)$, Pretilachlor @ 750g a.i. ha ${ }^{-1}$ at $7 \mathrm{DAS}\left(\mathrm{T}_{4}\right), 2,4$ D@ 1000 g a.i. ha ${ }^{-1}$ at 20 - 25 DAS(T $\left(\mathrm{T}_{5}\right)$, Pyrazosulfuron ethyl @ $25 \mathrm{~g}$ a.i. ha ${ }^{-1}$ at 20 - 25 DAS ( $\left.\mathrm{T}_{6}\right)$, Butachlor @ $1500 \mathrm{~g}$ a.i. $\mathrm{ha}^{-1}$ at $7 \mathrm{DAS}+2,4 \mathrm{D} @ 1000 \mathrm{~g}$ a.i.ha ${ }^{-1}$ at $20-25 \mathrm{DAS}\left(\mathrm{T}_{7}\right)$, Butachlor@1500 g a.i. ha ${ }^{-1}$ at 7 DAS + Pyrazosulfuron ethyl @ $25 \mathrm{~g}$ a.i.ha ${ }^{-1}$ at 20 - $25 \mathrm{DAS}\left(\mathrm{T}_{8}\right)$, Pretilachlor @ $750 \mathrm{~g}$ a.i. $\mathrm{ha}^{-1}$ at $7 \mathrm{DAS}+2,4 \mathrm{D} @ 1000 \mathrm{~g}$ a.i. ha ${ }^{-1}$ at $20-25 \mathrm{DAS}\left(\mathrm{T}_{9}\right)$, Pretilachlor@750 g a.i. ha ${ }^{-1}$ at 7 DAS + Pyrazosulfuron ethyl @ $25 \mathrm{~g}$ a.i.ha ${ }^{-1}$ at 20 - 25 DAS $\left(\mathrm{T}_{10}\right)$ thereby making Ten treatment combinations replicated three times. The soil of experimental plot was low in available nitrogen $(230.71 \mathrm{~kg}$ $\left.\mathrm{ha}^{-1}\right)$, high in available phosphorus $\left(31.76 \mathrm{~kg} \mathrm{ha}^{-1}\right)$ and organic carbon $(0.58 \%)$ and low in available potash $\left(280.53 \mathrm{~kg} \mathrm{ha}^{-1}\right)$ as regards to fertility status and slightly alkaline in reaction ( $\mathrm{pH}$ 7.8). The soil of the experimental field was clayey in texture. The crop variety PKV- Khamang was used in experiments. Gross plot size was $4.2 \mathrm{~m} \times 4.5 \mathrm{~m}$ and net plot size was $3.6 \mathrm{~m} \times 4.2 \mathrm{~m}$. Full dose of phosphorus and potash applied at time sowing and half nitrogen were applied at sowing and remaining dose of $\mathrm{N}$ was applied at 30 and 60 DAS. Butachlor, 2, $4-\mathrm{D}$, pretilachlor and pyrazosulfuron ethyl are the commercial products used as herbicides in experiment. Each herbicide was mixed with 2 litres of water and then sprayed uniformly. Pre harvest observation like Height of plant $(\mathrm{cm})$, Number of effective tillers hill ${ }^{-1}$ and at the time of harvesting Number of panicles hill ${ }^{-1}$, Number of grains panicle ${ }^{-1}$, Yield of grains hill $^{-1}(\mathrm{~g})$, Yield of straw hill ${ }^{1}(\mathrm{~g})$, Test weight $(\mathrm{g})$, Yield of grains $\left(\mathrm{q} \mathrm{ha} \mathrm{h}^{-1}\right)$, Yield of straw $\left(\mathrm{q} \mathrm{ha}^{-1}\right)$ and Harvest index $(\%)$ were recorded. In order to represent the plot, five plants of rice from each net plot were selected randomly for various biometric observations on post harvest studies. The selected five plants were labeled and all biometric observations were recorded properly on them.

\section{Weed studies}

Weed flora was studied from each plot under different weed control treatments at 30 days interval. Weeds from one square meter area identified. After identification weed were classified into monocots, dicots and perennials. The number of weeds under each of the class was recorded. Finally the total dry weight of weeds prior to harvest was recorded.

\section{Weed count}

For weed count studies one meter iron quadrate was used. Weed count was taken from single place in each plot by placing iron quadrate. All the weeds present in the quadrate were carefully counted and categorized into groups namely monocot, dicot and then take total weed count.

\section{Dry matter of weed $\mathrm{m}^{-2}(\mathrm{~g})$}

Treatment wise weeds were taken at 30, 60, 90 DAS and at harvest. First sun dried and then kept in hot air oven at $60^{\circ} \mathrm{C}$ for drying for till the constant weight obtained. After drying the samples were weighed on electric balance.

Weed index
It indicates decrease in yield due to presence of weeds as compared to weed free plot. It is expressed as the competition offered by the weeds and is measured in terms of \% reduction in yield due to their presence in the yield. It can be expressed as,<smiles>[Y]C([Y4])([Y])C([Y])([Y])C#N</smiles>

Where,

$\mathrm{X}=$ Yield from weed free plot

$\mathrm{Y}=$ Yield from treatment plot for which WI is to be calculated.

Lesser the weed index, better is the efficacy of herbicide.

\section{Weed control efficiency}

Weed control efficiency denotes the efficacy of different treatments to control weeds. It is expressed in percentage. It was calculated by using following formula,

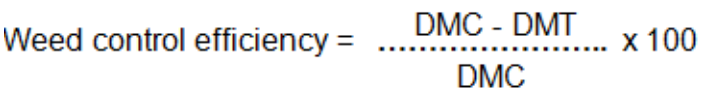

Where,

DMC $=$ Dry matter production of weed in control plot

DMT $=$ Dry matter production of weeds in treated plot.

Higher the weed control efficiency, better is the efficacy of herbicide.

\section{Detail of herbicides used \\ Butachlor}

Common name: Butachlor.

Trade name: Machete.

Chemical name: $\mathrm{N}$ - butaxymethyl -2- chloro-2:6' diethyl acetanilide.

Doses: 1.0 - $4.5 \mathrm{~kg}$ a.i. $\mathrm{ha}^{-1}$. It is a selective types of herbicide. Application: Pre-emergence,

Mode of action: It is rapidly absorbed by the germinated shoots and secondarily by the roots, with translocation through the plant.

Type of weed control: Control of annual grasses and certain broad- leaved weeds in rice.

\section{Structural formula}

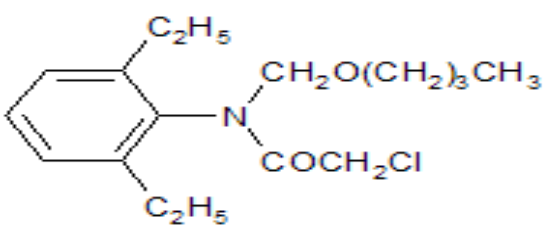

\section{2, 4-D}

Common name: $2,4-\mathrm{D}$.

Trade name: Weedmar.

Chemical name: 2,4- dichlorophenoxy acetic acid.

Empiricla formula: $\mathrm{C}_{8} \mathrm{H}_{6} \mathrm{C}_{12} \mathrm{O}_{3}$.

Doses: $0.28-2.3 \mathrm{~kg} \mathrm{ha}^{-1}$.

Type of herbicide: Selective.

Application: Post- emergence.

Mode of action: Salt is readily absorbed by roots, while esters are readily absorbed by the foliage. Translocation occurs at the meristematic regions of shoots and roots. 
Type of weed control: Control of annual and perennial broad- leaved weeds in cereals.

\section{Structural formula}<smiles>O=C(O)COc1ccc(Cl)cc1Cl</smiles>

Pretilachlor

Common name: Pretilachlor. Trade name: Refit.

Chemical name: 2- chloro-N - (2, 6-diethylphenyl) $-\mathrm{H}-$ (2-propoxyethyl) $=$ acetamide. Empirical Name: $\mathrm{C}_{17} \mathrm{H}_{26} \mathrm{ClNO}_{2}$. Doses: $0.75 \mathrm{~kg} \mathrm{ha}^{-1}$.

Types of herbicide: Selective herbicide.

Application: Pre-emergence.

Mode of action: It is taken up readily by the hypocotyls, mesocotyls and coleoptile and by the roots of geminating weeds.

Types of weed control: Annual grasses, broad leaved weeds and sedges in transplanted and seeded rice.

\section{Structural formula}

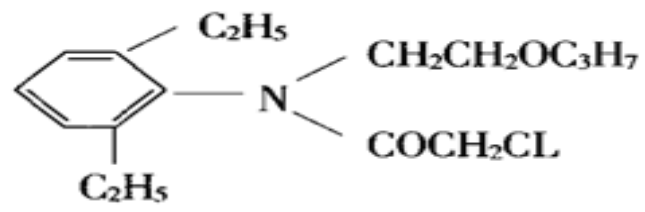

Pyrazosulfuron ethyl

Common name: Pyrazosulfuron ethyl.

Trade name: Sathi.

Chemical name: Ethyl-5 (4,6 dimethoxy-2- pyrimidinyl) amino) carbonyl) amino) sulfonyl)-1 methyl-1H pyrazole- 4carboxylate.

Empirical formula: $\mathrm{C}_{14} \mathrm{H}_{18} \mathrm{~N}_{6}$. Doses: 15 - $30 \mathrm{~g} \mathrm{ha}^{-1}$.

Type of Herbicide: Selective.

Application: Pre or early post emergence.

Mode of action: It is absorbed by roots or leaves and translocated to the meristem.

Type of weed control: Annual, perennial broad leaved weeds and sedges.

\section{Structural formula}<smiles>CCOC(=O)c1cnn(C)c1S(=O)(=O)NC(=O)Nc1nc(OC)cc(OC)n1</smiles>

\section{Results and Discussion}

\section{Effect of treatments on weed population}

The weeds were classified in two major groups i.e. monocot and dicot weed to study the effect of different treatments on each group. The data regarding the mean number of monocot and dicot weed population $\mathrm{m}^{-2}$ and total weed population (Monocot and dicot) $\mathrm{m}^{-2}$ influenced periodically at 30 days interval by different treatments are presented in Table 1 .

Table 1: Effect of cultural and chemical weed management on weed population and economics in Drilled Paddy (Oryza sativa L.)

\begin{tabular}{|c|c|c|c|c|c|c|c|c|c|c|c|}
\hline & Treatment & $\begin{array}{c}\text { Mean } \\
\text { monot } \\
\text { weed } \\
\text { count }\left(\mathrm{m}^{-}\right. \\
2)\end{array}$ & $\begin{array}{c}\text { Mean } \\
\text { dicot } \\
\text { weed } \\
\text { count }\left(\mathrm{m}^{-}\right. \\
2)\end{array}$ & $\begin{array}{c}\text { Mean } \\
\text { total } \\
\text { weed } \\
\text { count }\left(\mathrm{m}^{-}\right. \\
2)\end{array}$ & $\begin{array}{c}\text { Mean } \\
\text { weed dry } \\
\text { matter } \\
\left(\mathbf{m}^{-2}\right) \mathrm{g}\end{array}$ & $\begin{array}{c}\text { Mean } \\
\text { weed } \\
\text { index } \\
(\%)\end{array}$ & $\begin{array}{c}\text { Weed } \\
\text { control } \\
\text { efficiency } \\
(\%)\end{array}$ & $\begin{array}{c}\text { Gross } \\
\text { monetary } \\
\text { Return (Rs. } \\
\left.\text { ha' }^{-1}\right)\end{array}$ & $\begin{array}{c}\text { Cost of } \\
\text { cultivation } \\
(\text { Rs. ha-1) }\end{array}$ & $\begin{array}{c}\text { Net } \\
\text { monetary } \\
\text { return (Rs. } \\
\left.\text { ha' }^{-1}\right)\end{array}$ & $\begin{array}{l}\mathrm{B}: \mathrm{C} \\
\text { ratio }\end{array}$ \\
\hline $\mathrm{T}_{1}$ & Control & $\begin{array}{c}4.95 \\
(24.00) \\
\end{array}$ & $\begin{array}{c}4.95 \\
(24.08) \\
\end{array}$ & $\begin{array}{c}6.97 \\
(48.08)\end{array}$ & $\begin{array}{c}14.09 \\
(198.20)\end{array}$ & 58.48 & ---- & 24484 & 18465 & 6019 & 1.33 \\
\hline $\mathrm{T}_{2}$ & $\begin{array}{c}\text { Two hand weeding at } 20 \\
\text { and } 40 \text { DAS }\end{array}$ & $\begin{array}{c}2.84 \\
(7.67) \\
\end{array}$ & $\begin{array}{c}2.74 \\
(7.03)\end{array}$ & $\begin{array}{c}3.88 \\
(14.59) \\
\end{array}$ & $\begin{array}{c}6.40 \\
(40.46) \\
\end{array}$ & ----- & 79.58 & 57963 & 21345 & 36618 & 2.72 \\
\hline $\mathrm{T}_{3}$ & $\begin{array}{c}\text { Butachlor @ } 1500 \mathrm{~g} \text { a.i. } \\
\text { ha }^{-1} \text { at } 7 \text { DAS }\end{array}$ & $\begin{array}{c}4.33 \\
(18.26) \\
\end{array}$ & $\begin{array}{c}3.75 \\
(13.54)\end{array}$ & $\begin{array}{c}5.68 \\
(31.80)\end{array}$ & $\begin{array}{c}8.80 \\
(76.87) \\
\end{array}$ & 39.00 & 61.22 & 35550 & 19515 & 16035 & 1.82 \\
\hline $\mathrm{T}_{4}$ & $\begin{array}{c}\text { Pretilachlor @ } 750 \text { g a.i. } \\
\text { ha }^{-1} \text { at } 7 \text { DAS }\end{array}$ & $\begin{array}{c}4.39 \\
(18.76) \\
\end{array}$ & $\begin{array}{c}4.01 \\
(15.63) \\
\end{array}$ & $\begin{array}{c}5.90 \\
(34.39) \\
\end{array}$ & $\begin{array}{c}8.97 \\
(80.06) \\
\end{array}$ & 43.80 & 59.61 & 32933 & 19200 & 13733 & 1.72 \\
\hline $\mathrm{T}_{5}$ & $\begin{array}{c}2,4 \text { - D @ } 1000 \mathrm{~g} \text { a.i. ha }{ }^{-1} \\
\text { at } 20 \text { - 25 DAS }\end{array}$ & $\begin{array}{c}4.51 \\
(19.88) \\
\end{array}$ & $\begin{array}{c}3.87 \\
(14.48) \\
\end{array}$ & $\begin{array}{c}5.90 \\
(34.36) \\
\end{array}$ & $\begin{array}{c}8.99 \\
(80.42)\end{array}$ & 49.24 & 59.42 & 29790 & 18865 & 10925 & 1.58 \\
\hline $\mathrm{T}_{6}$ & $\begin{array}{c}\text { Pyrazosulfuron ethyl @ 25 } \\
\text { g a.i. ha }{ }^{-1} \\
\text { at } 20-25 \text { DAS }\end{array}$ & $\begin{array}{c}4.43 \\
(19.18)\end{array}$ & $\begin{array}{c}4.08 \\
(16.17)\end{array}$ & $\begin{array}{c}5.98 \\
(35.35)\end{array}$ & $\begin{array}{c}9.06 \\
(81.68)\end{array}$ & 46.88 & 58.79 & 31210 & 19465 & 11745 & 1.60 \\
\hline $\mathrm{T}_{7}$ & $\begin{array}{c}\text { Butachlor @ } 1500 \text { g a.i. } \\
\text { ha }^{-1} \text { at } 7 \text { DAS }+2,4-\mathrm{D} @ \\
1000 \text { g a.i. ha }{ }^{-1} \text { at } 20 \text { - } 25 \\
\text { DAS } \\
\end{array}$ & $\begin{array}{c}3.32 \\
(10.57)\end{array}$ & $\begin{array}{c}3.06 \\
(8.86)\end{array}$ & $\begin{array}{c}4.46 \\
(19.43)\end{array}$ & $\begin{array}{c}6.91 \\
(47.39)\end{array}$ & 5.84 & 76.09 & 53650 & 19915 & 33735 & 2.69 \\
\hline $\mathrm{T}_{8}$ & $\begin{array}{c}\text { Butachlor @ } 1500 \text { g a.i. } \\
\text { ha }^{-1} \text { at } 7 \text { DAS + } \\
\text { Pyrazosulfuron ethyl @ 25 } \\
\text { g a.i. ha }{ }^{-1} \text { at } 20-25 \text { DAS }\end{array}$ & $\begin{array}{c}3.37 \\
(10.86)\end{array}$ & $\begin{array}{c}3.12 \\
(9.28)\end{array}$ & $\begin{array}{c}4.54 \\
(20.14)\end{array}$ & $\begin{array}{c}7.00 \\
(48.53)\end{array}$ & 9.91 & 75.51 & 52073 & 20515 & 31558 & 2.54 \\
\hline $\mathrm{T}_{9}$ & $\begin{array}{c}\text { Pretilachlor @ 750 g a.i. } \\
\text { ha }^{-1} \text { at } 7 \text { DAS }+2,4-\text { D @ } \\
1000 \text { g a.i. ha } a^{-1} \text { at } 20-25 \\
\text { DAS } \\
\end{array}$ & $\begin{array}{c}3.41 \\
(11.12)\end{array}$ & $\begin{array}{c}3.24 \\
(9.98)\end{array}$ & $\begin{array}{c}4.64 \\
(21.10)\end{array}$ & $\begin{array}{c}7.04 \\
(49.19)\end{array}$ & 11.90 & 75.18 & 50927 & 19600 & 31327 & 2.60 \\
\hline $\mathrm{T}_{10}$ & $\begin{array}{c}\text { Pretilachlor @ 750 g a.i. } \\
\text { ha }^{-1} \text { at } 7 \text { DAS + } \\
\text { Pyrazosulfuron ethyl @ 25 }\end{array}$ & $\begin{array}{c}3.49 \\
(11.69)\end{array}$ & $\begin{array}{c}3.29 \\
(10.36)\end{array}$ & $\begin{array}{c}4.75 \\
(22.05)\end{array}$ & $\begin{array}{c}7.09 \\
(49.89)\end{array}$ & 16.82 & 74.82 & 48203 & 20200 & 28003 & 2.39 \\
\hline
\end{tabular}




\begin{tabular}{|c|c|c|c|c|c|c|c|c|c|c|}
\hline g a.i. ha $^{-1}$ at $20-25$ DAS & & & & & & & & & & \\
\hline $\mathrm{SE}(\mathrm{m}) \pm$ & 0.23 & 0.20 & 0.29 & 0.24 & -- & -- & 3289 & -- & 2921 & -- \\
\hline CD at $5 \%$ & 0.69 & 0.60 & 0.87 & 0.72 & -- & -- & 9774 & -- & 8680 & -- \\
\hline GM & $\begin{array}{c}3.90 \\
(15.18)\end{array}$ & $\begin{array}{c}3.61 \\
(12.94)\end{array}$ & $\begin{array}{c}5.27 \\
(28.13)\end{array}$ & $\begin{array}{c}8.43 \\
(74.94)\end{array}$ & 28.19 & 62.02 & 41678 & -- & 21970 & -- \\
\hline
\end{tabular}

Fig. in parenthesis are actual value

Upper values are transformed values $\mathrm{X}+\sqrt{0.5}$

The treatment control $\left(\mathrm{T}_{1}\right)$ recorded the highest monocot, dicot and total weed population and two hand weeding at 20 and 40 DAS $\left(\mathrm{T}_{2}\right)$ were significantly superior in reducing monocot, dicot and total weed population over all treatments at all growth stages.

Monocot, dicot and total weed population were reduced significantly due to various weed control treatments at all growth stages. The lowest density of monocot, dicot and total weeds recorded with two hand weeding at 20 and 40 DAS $\left(\mathrm{T}_{2}\right)$ was significantly superior over all treatments at all growth stages. However, it was at par with treatment butachlor@1500 g a.i. ha ${ }^{-1}$ at 7 DAS + 2,4-D @ $1000 \mathrm{~g} \mathrm{a.i.g}$ $\mathrm{ha}^{-1}$ at 20 - 25 DAS $\left(\mathrm{T}_{7}\right)$, butachlor @ $1500 \mathrm{~g}$ a.i. ha ${ }^{-1}$ at 7 DAS + pyrazosulfuron ethyl @ 25 g a.i. ha ${ }^{-1}$ at $20-25$ DAS $\left(\mathrm{T}_{8}\right)$, pretilachlor@ $750 \mathrm{~g}$ a.i. ha ${ }^{-1}$ at $7 \mathrm{DAS}+2,4-\mathrm{D} @ 1000$ g a.i. ha ${ }^{-1}$ at $20-25$ DAS $\left(\mathrm{T}_{9}\right)$ and pretilachlor @ $750 \mathrm{~g}$ a.i. ha ${ }^{1}+$ pyrazosulfuron ethyl @ $25 \mathrm{~g}$ a.i. ha ${ }^{-1}$ at 20 - 25 DAS $\left(\mathrm{T}_{10}\right)$. Two hand weeding at 20 and 40 DAS and combination of herbicide application provide effective control of monocot and dicot weeds.

Total weed population (monocot and dicot) was reduced significantly due to various weed control treatments at all growth stages due to the reason of lower weed population under mechanical and herbicidal treatment than control treatments by the mechanical treatment of two hand weeding. This might be due to increased weed control efficiency due to sequential weeding. Similar results were reported by Gopinath and Pandey (2006).

\section{Effect of treatments on dry matter accumulation of weeds}

Data pertaining to the weed dry matter produced by the weeds $\mathrm{m}^{-2}$ was presented in Table 1 .

Dry weight of weeds showed increasing trend up to harvest stage.. All the weed control treatments brought significant reduction in weed dry matter as compared to control treatment. The highest reduction of weed dry matter was found in two hand weeding at 20 and 40 DAS $\left(\mathrm{T}_{2}\right)$ and was at par with treatments, butachlor @ $1500 \mathrm{~g}$ a.i. ha ${ }^{-1}$ at 7 DAS + 2,4-D@1000 g a.i.g ha ${ }^{-1}$ at 20 - 25 DAS $\left(\mathrm{T}_{7}\right)$, butachlor @ $1500 \mathrm{~g}$ a.i. ha ${ }^{-1}$ at 7 DAS + pyrazosulfuron ethyl @ $25 \mathrm{~g}$ a.i. ha $^{-1}$ at $20-25$ DAS $\left(\mathrm{T}_{8}\right)$, pretilachlor @ $750 \mathrm{~g}$ a.i. ha ${ }^{-1}$ at 7 DAS + 2,4-D@1000 g a.i. ha ${ }^{-1}$ at 20 - 25 DAS $\left(\mathrm{T}_{9}\right)$ and pretilachlor @ $750 \mathrm{~g}$ a.i. ha ${ }^{-1}+$ pyrazosulfuron ethyl @ $25 \mathrm{~g}$ a.i. ha ${ }^{-1}$ at $20-25$ DAS $\left(\mathrm{T}_{10}\right)$ at all the growth stages. Obviously this was due to higher reduction in weed population. The finding correlates with the findings of Singh and Singh (2006) ${ }^{[12]}$, Sharma et al. (2007) ${ }^{[11]}$, Rajkhowa and Barua (2007) ${ }^{[8]}$, Rajkhowa et al. (2007) ${ }^{[9]}$ and Banerjee et al. $(2008)^{[3]}$.

Effect on weed index (\%) and Weed control efficiency (\%) Data pertaining to weed index $(\%)$ and Weed control efficiency $(\%)$ influenced by different weed control treatments are presented in Table 1.

Weed index was computed as the yield reduction comparative to highest yielding treatment i.e. two hand weeding at 20 and 40 DAS $\left(\mathrm{T}_{2}\right)$. Among weed management practices, butachlor @ $1500 \mathrm{~g}$ a.i. ha ${ }^{-1}$ at $7 \mathrm{DAS}+2,4-\mathrm{D} @ 1000 \mathrm{~g}$ a.i. $\mathrm{g} \mathrm{ha}{ }^{-1}$ at 20
- 25 DAS $\left(\mathrm{T}_{7}\right)$ showed minimum weed index (5.84) over all the other treatments followed by butachlor @ $1500 \mathrm{~g}$ a.i. ha ${ }^{-1}$ at 7 DAS + pyrazosulfuron ethyl @ $25 \mathrm{~g}$ a.i. ha ${ }^{-1}$ at $20-25$ DAS $\left(\mathrm{T}_{8}\right)$, pretilachlor@ $950 \mathrm{~g}$ a.i. ha ${ }^{-1}$ at 7 DAS + 2,4-D @ $1000 \mathrm{~g}$ a.i. ha ${ }^{-1}$ at 20 - 25 DAS $\left(\mathrm{T}_{9}\right)$ and pretilachlor @ $750 \mathrm{~g}$ a.i. ha $\mathrm{h}^{-1}+$ pyrazosulfuron ethyl @ $25 \mathrm{~g}$ a.i. ha ${ }^{-1}$ at $20-25$ DAS $\left(\mathrm{T}_{10}\right)$. Control treatment $\left(\mathrm{T}_{1}\right)$ recorded maximum weed index i.e. (58.48) indicating the reduction in paddy grain yield due to presence of weeds throughout crop growth period.

Lower weed index in mechanical weed control practices might be due to better weed control which provides favorable conditions for crop growth which ultimately increased the grain yield of paddy crop as compared to control treatment $\left(\mathrm{T}_{1}\right)$.

Treatment two hand weeding at 20 and 40 DAS $\left(T_{2}\right)$ was recorded highest weed control efficiency as compared to other treatments at all growth stages. However treatments butachlor @ $1500 \mathrm{~g}$ a.i. ha ${ }^{-1}$ at $7 \mathrm{DAS}+2,4-\mathrm{D} @ 1000 \mathrm{~g}$ a.i. $\mathrm{g} \mathrm{ha}^{-1}$ at 20 - 25 DAS $\left(\mathrm{T}_{7}\right)$, butachlor @ $1500 \mathrm{~g}$ a.i. ha ${ }^{-1}$ at 7 DAS + pyrazosulfuron ethyl @ $25 \mathrm{~g}$ a.i. ha ${ }^{-1}$ at $20-25$ DAS $\left(\mathrm{T}_{8}\right)$, pretilachlor@750 g a.i. ha ${ }^{-1}$ at 7 DAS + 2,4-D @ $1000 \mathrm{~g}$ a.i. ha $^{-1}$ at 20 - 25 DAS $\left(\mathrm{T}_{9}\right)$ and pretilachlor @ $750 \mathrm{~g}$ a.i. ha ${ }^{-1}+$ pyrazosulfuron ethyl @25 g a.i. ha ${ }^{-1}$ at $20-25$ DAS $\left(\mathrm{T}_{10}\right)$ which were at par with each other. The lowest weed control efficiency was found in control treatment. These could be due to better control of weeds by hand weedings and application of herbicide combination. These results were in agreement to that of Singh and Singh (2006) ${ }^{[12]}$, Halder and Patra (2007) [5], Sharma et al. (2007) ${ }^{[11]}$, Bali et al. (2004) ${ }^{[2]}$ and Singh and Singh (2010).

\section{Economics studies}

Considering the prevailing cost of labour and inputs required for weed control treatments economics was worked out for various treatments and data are presented in Table 1.

The treatment of two hand weeding at 20 and 40 DAS $\left(\mathrm{T}_{2}\right)$ significantly recorded maximum GMR (Rs. 57963 ha $^{-1}$ ), NMR (Rs. $36618 \mathrm{ha}^{-1}$ ) and benefit: cost ratio (2.72) followed by butachlor @ $1500 \mathrm{~g}$ a.i. ha ${ }^{-1}$ at 7 DAS + 2,4-D @ $1000 \mathrm{~g}$ a.i. $\mathrm{g} \mathrm{ha}^{-1}$ at 20 - $25 \mathrm{DAS}\left(\mathrm{T}_{7}\right)$, butachlor @ $1500 \mathrm{~g}$ a.i. ha $^{-1}$ at 7 DAS + pyrazosulfuron ethyl @ $25 \mathrm{~g}$ a.i. ha ${ }^{-1}$ at $20-25$ DAS $\left(\mathrm{T}_{8}\right)$, pretilachlor @ $750 \mathrm{~g}$ a.i. ha ${ }^{-1}$ at $7 \mathrm{DAS}+2,4-\mathrm{D} @ 1000$ g a.i. ha ${ }^{-1}$ at 20 - 25 DAS $\left(\mathrm{T}_{9}\right)$ and pretilachlor @ $750 \mathrm{~g}$ a.i. ha ${ }^{1}+$ pyrazosulfuron ethyl @ $25 \mathrm{~g}$ a.i. ha ${ }^{-1}$ at $20-25$ DAS $\left(\mathrm{T}_{10}\right)$. However, in respect of all these treatments were at par with two hand weeding at 20 and $40 \mathrm{DAS}\left(\mathrm{T}_{2}\right)$. Control treatment $\left(\mathrm{T}_{1}\right)$ recorded minimum GMR (Rs. $24484 \mathrm{ha}^{-1}$ ) and NMR (Rs. 6019 ha $\left.^{-1}\right)$. Least Benefit cost ratio (1.33) was observed in control $\left(\mathrm{T}_{1}\right)$ as a result of higher crop weed competition which reduced the paddy yield significantly.

The highest gross monetary return and net monetary return might be due to higher grain yield of paddy which is attributed due to effective control of weeds by these treatments that is then have positive effect on crop growth and yield. Similar results are reported by Raju and Pandain (2002) ${ }^{[10]}$, Singh and Singh (2010), Kachroo and Bazaya (2011) ${ }^{[6]}$, Gopinath et al. (2012) ${ }^{[4]}$. 


\section{Conclusions}

Significant reduction in population, higher weed control efficiency, lowest dry matter of monocot and dicot weeds were recorded by butachlor @ $1500 \mathrm{~g}$ a.i. ha ${ }^{-1}$ at 7 DAS + 2,4D@ 1000 g a.i. $\mathrm{g} \mathrm{ha}^{-1}$ at 20 - 25 DAS $\left(\mathrm{T}_{7}\right)$ or butachlor @ $1500 \mathrm{~g}$ a.i. ha ${ }^{-1}$ at 7 DAS + pyrazosulfuron ethyl @ $25 \mathrm{~g}$ a.i. $\mathrm{ha}^{-1}$ at $20-25$ DAS $\left(\mathrm{T}_{8}\right)$ or pretilachlor @ $750 \mathrm{~g}$ a.i. ha $^{-1}$ at 7 DAS + 2,4-D@1000 g a.i. ha ${ }^{-1}$ at 20 - 25 DAS $\left(\mathrm{T}_{9}\right)$ or pretilachlor@750 g a.i. ha ${ }^{-1}+$ pyrazosulfuron ethyl @ $25 \mathrm{~g}$ a.i. ha ${ }^{-1}$ at $20-25$ DAS $\left(\mathrm{T}_{10}\right)$. Higher net monetary return and B : C ratio was obtained by butachlor @ $1500 \mathrm{~g}$ a.i. ha ${ }^{-1}$ at 7 $\mathrm{DAS}+2,4-\mathrm{D} @ 1000 \mathrm{~g}$ a.i. $\mathrm{g} \mathrm{ha} \mathrm{ha}^{-1}$ at $20-25 \mathrm{DAS}\left(\mathrm{T}_{7}\right)$ or butachlor@1500 g a.i. ha $a^{-1}$ at 7 DAS + pyrazosulfuron ethyl @ $25 \mathrm{~g}$ a.i. ha ${ }^{-1}$ at 20 - 25 DAS $\left(\mathrm{T}_{8}\right)$ or pretilachlor @ $750 \mathrm{~g}$ a.i. ha ${ }^{-1}$ at 7 DAS + 2,4-D @ 1000 g a.i. ha ${ }^{-1}$ at $20-25$ DAS $\left(\mathrm{T}_{9}\right)$ or pretilachlor @ $750 \mathrm{~g}$ a.i. ha ${ }^{-1}+$ pyrazosulfuron ethyl @ $25 \mathrm{~g}$ a.i. ha $\mathrm{h}^{-1}$ at 20 - 25 DAS $\left(\mathrm{T}_{10}\right)$ which clearly shows that economic viability of treatments $\mathrm{T}_{7}$ followed by $\mathrm{T}_{8}, \mathrm{~T}_{9}$ and $\mathrm{T}_{10}$ over control.

\section{References}

1. Anonymous. Directorate of Economics and Statistics, Department of Agriculture and Cooperation, Ministry of Agriculture, Government of India, New Delhi, 2014. (www.agricoop.nic.in).

2. Bali AS, Gonai BA, Kotru R. Weed control in transplanted rice (Oryza sativa). Indian J. Agron. 2004; 39(1):16-18.

3. Banerjee PD, Bandyopadhyay DP, Maity D. Production potential, water use efficiency and economics of hybrid rice under different levels of irrigation and weed management practices. Oryza. 2008; 45(1):30-35.

4. Gopinath KA, Mina BL, Singh KP, Natrajan KC. Integrated weed management in direct-seeded rainfed rice (Oryza sativa). Indian J. Agron. 2012; 57(3):245249.

5. Halder J, Patra AK. Effect of chemical weed control methods on productivity of transplanted rice. Indian J. Agron. 2007; 52(2):111-113.

6. Kachroo D, Bazaya BR. Efficacy of different herbicides on growth and yield of direct wet seeded rice sown through drum seeder. Indian J. Weed Sci. 2011; 43(1 \& 2):67-69.

7. Patra AK, Halder J, Mishra MM. Chemical weed control in transplanted rice in Hirakud command area of Orissa. Indian J. Weed Sci. 2011; 43(3 \& 4):175-177.

8. Rajkhowa DJ, Deka NC, Borah N, Barua. Effect of herbicides with or without paddy weeder on Swedes in transplanted summer rice. Indian J. Agron. 2007; 52(2):107-110.

9. Rajkhowa DJ, Deka NC, Borah N, Barua. Effect of herbicides with or without paddy weeder on Swedes in transplanted summer rice. Indian J. Agron. 2007; 52(2):107-110.

10. Raju M, Pandian BJ. Performance of wet seeded rice under different weed management practices. Oryza. 2002; 30(1 \& 2):45-47.

11. Sharma RP, Pathak SK, Singh RC. Effect of nitrogen and weed management in direct seeded rice under upland condition. Indian J. Agron. 2007; 52(2):114-119.

12. Singh Parmeet, Singh SS. Herbicide efficacy in seeded rice with different methods under wet and dry condition. Indian J. Weed Sci. 2006; 41(1 \& 2):37-40. 